\title{
Európai Rákellenes Kódex: 12 lehetöség, hogy csökkentse a rák kialakulásának kockázatát
}

\author{
Döbrőssy Lajos dr. ${ }^{1}$ - Cornides Ágnes dr. ${ }^{2}$ \\ ${ }^{1}$ Országos Tisztifóorvosi Hivatal, Budapest \\ ${ }^{2}$ Budapest Fôváros Kormányhivatala, Népegészségügyi Főosztály, Budapest
}

\begin{abstract}
A WHO Nemzetközi Rákkutatási Ügynöksége a közelmúltban adta közre az Európai Rákellenes Kódex negyedik, átdolgozott kiadását. Ebben a rosszindulatú daganatos betegségek előfordulásának mérséklésére szolgáló, személyre szóló tanácsokat 12 pontban foglalja össze. A tanácsok egy része a daganatkeletkezésben bizonyítottan szerephez jutó, többségükben a mindennapi életmóddal összefüggő kockázati tényezők kivédésére szolgál, más része pedig az egészségügyi ellátórendszer által nyújtott szolgáltatások elfogadására buzdít. A szerzők úgy vélik, a Rákellenes Kódex hazánkban ez ideig nem kapott érdeme szerinti nyilvánosságot az egészségügyi szolgáltatók körében. Minthogy az idő előtti halálozásért legnagyobb mértékben okolható nem fertőző idült betegségek nagy hányadának kialakulásában közös kockázati tényezổ is részt vesznek, a kódex tanácsai egyszerre szolgálják a keringési rendszer betegségeinek és a daganatos betegségek megelőzésének ügyét. Orv. Hetil., 2016, 157(12), 451-460.
\end{abstract}

Kulcsszavak: életmód, egészségtudatosság, egészségnevelés

\section{European Code against Cancer: 12 ways to reduce your cancer risk}

Recently, the Word Health Organization/International Agency for Research on Cancer published the 4th edition of European Code against Cancer with 12 personal advices on how to diminish the risk of development of cancer. A proportion of advices refers to risk factors which are connected to our everyday lifestyle; an other admonishes to comply with the services offered by the health care system. In Hungary, the European Code has not received adequate publicity so far. As common risk factors play a major role in the development of chronic non-communicable diseases, the advices may contribute to the prevention of both cardiovascular diseases and cancer.

Keywords: lifestyle, health-consciousness, health education

Döbrössy, L., Cornides, Á. [European Code against Cancer: 12 ways to reduce your cancer risk.] Orv. Hetil., 2016, $157(12), 451-460$.

(Beérkezett: 2015. december 18.; elfogadva: 2016. január 15.)

A rosszindulatú daganatok által okozott, az egyes személyekre és a társadalom egészére háruló betegségteher egyre súlyosabb. 2012-ben világszerte 14,1 millió új megbetegedést regisztráltak, és 8,2 millió személy halt meg rákbetegségben [1]. Európában, 2012-ben (nem számítva a bőr nem festékes daganatait) a rákos megbetegedések számát 3,45 millióra, a bekövetkezett halálesetek számát 1,5 millióra becsülik [2]. A rák miatt bekövetkezett halálozás - a szív- és érbetegségek mögött - a halálokok között a második helyen áll. Az EUROSTAT adatközlése szerint a 2000-2010 közötti évtizedben az EU-28 országaiban a korábbi évekhez viszonyítva a rák okozta halálozás 7,2\%-kal emelkedett [3]. Magyar- országon 2012-ben a Nemzeti Rákregiszter 65116 új megbetegedést, a Központi Statisztikai Hivatal pedig 33790 halálesetet jelentett. A rákbetegség által okozott emberi szenvedés és a társadalomra nehezedő teher számokkal nem fejezhető ki.

A rák okaira vonatkozó ismereteink mindmáig hiányosak; csak a betegség kialakulásában szerepet játszó kockázati tényezốket ismerjük. Mai tudásunk szerint a daganatos betegségeknek, így az azokból következő halálozásnak csak kis hányada vezethető vissza genetikailag meghatározott, tehát öröklődő, „belső” tényezőkre, jelentős hányadát külső, környezeti tényezők okozzák, természetesen molekuláris mechanizmusokon keresztül. 
Korábban fontosabbnak vélték a külső környezet, azaz a fizikai, kémiai, biológiai tényezők szerepét (víz-, levegő-, talajszennyeződés, munkahelyi környezet, ipari folyamatok és termékek). Újabban a személyes környezet, az egészségre hatást gyakorló szokások, divatos szóval az „életmóddal” összefüggő tényezők kapnak nagyobb hangsúlyt. Ilyen, az életmóddal összefüggő kockázati tényezők a dohányzás, egészségtelen táplálkozás, a mérték feletti alkoholfogyasztás, mozgásszegény életvitel, elhízás, drogfogyasztás, túlzásba vitt napozás, a szexuális és reproduktív tevékenységhez kapcsolódó szokások. Az életmóddal összefüggő kockázati tényezők szerepét a rákkeletkezésben epidemiológiai adatok tömege bizonyítja $[4,5]$.

A kutatók becslése szerint a rosszindulatú daganatok nagy többsége tehát életmódfüggó és külső környezeti tényezökre vezethetó vissza $[4,6]$, arról azonban megoszlanak a szakértői vélemények, hogy egyik vagy másik hatása milyen mértékben érvényesül [7]. Szempontunkból az a lényeges, hogy mind a külső, mind a személyes környezetből, azaz az életmódból eredeztetett kockázati tényezők elkerülhetők, megváltoztathatók, kiiktathatók, következésképpen az általuk okozott daganatok kialakulásának kockázata csökkenthető, a rosszindulatú daganatok egy jelentós hányada megelözheto".

A betegségmegelőzés kulcsát az egészségmegörzés és egészségfejlesztés fogalmai adják a kezünkbe. Ezek - az Egészségügyi Világszervezet meghatározása szerint [8] - olyan fogalmak, amelyek az egészséges életmód, valamint az ezt ösztönző társadalmi, gazdasági, környezeti és kulturális tényezők támogatását jelentik. Arra ösztökélik az embereket, közösségeket, a társadalom egészét, hogy növeljék befolyásukat saját egészségük meghatározói felett.

A betegségmegelőzés stratégiája tehát kétféle lehet: az egészségvédelem érdekeit szem előtt tartó kormánypolitika és az egészségnevelés. Dolgozatunkban az utóbbi fontosságát hangsúlyozzuk azt remélve, hogy a betegségmegelőzés eredményessége mindenekelőtt az egyének életmódjának befolyásolásától remélhető. Ehhez kíván muníciót szolgáltatni az Európai Rákellenes Kódex, amely gyakorlati tanácsokkal szolgál a rosszindulatú daganatok megelőzésének lehetőségeiről abban a meggyőződésben, hogy a rosszindulatú daganatok mintegy harmada megelözheto", és a már kialakult betegségek fele meggyógyitható, ha az egyén tudatában van az életmódfüggó és külsö környezeti kockázati tényezők káros hatásainak, és egészségtudatos életvezetésével igyekszik azokat elkerülni, legalábbis hatásukat mérsékelni.

\section{Az Európai Rákellenes Kódex}

Ezekből az epidemiológiailag igazolt tényekből indult ki az akkori Európai Közösség (mai nevén Európai Unió) „Európa a rák ellen” elnevezésű nagyszabású programja, amikor 1987-ben első ízben közzé tette az „Európai Rákellenes Kódexet”, majd 1994-ben annak első revide- ált változatát [9], amely már tartalmazza az egyes tanácsok megindokolását szolgáló tudományos bizonyítékokat is. A kódex harmadik, majd negyedik revíziója [10, 11] tekintetbe veszi a tudományos kutatások újabb eredményeit (például HPV elleni oltás), és a korábbi „Tízparancsolatot" 12 ajánlássá bővítve adja közre (1. táblázat).

A kódex magyar nyelvű változatát Boyd és Eckhardt 1996-ban publikálta [12], majd annak negyedik revízióját [11] a Magyar Rákellenes Liga szórólapok formájában terjesztette (Simon Tamás személyes közlése). Mindazonáltal úgy véljük, hogy Magyarországon, ellentétben a nyugat-európai országokkal, az Európai Rákellenes Kódex nem kapott érdeme szerinti figyelmet. Ezt a hiányt igyekszik pótolni a dolgozat, amelynek alapját a kódex 4. kiadása szolgáltatta. Az Európai Rákellenes Kódex készítői

- figyelembe vették mindazokat a megingathatatlan tudományos bizonyítékokat, amelyek a káros hatások elkerülése, az egészséges életmód kialakítása, a szűrővizsgálaton való részvétel vagy az oltás haszna mellett szólnak;

- tanácsaikat közérthető, követhető formában fogalmazták meg;

- anélkül, hogy az egészségügyi döntéshozókat felmentenék felelősségük alól, az egyének által követendő és követhető cselekvésre helyezték a hangsúlyt: „Mit kell tennem a kockázat csökkentéséért?”, ennek köszönhetően

- a tanácsok követhetők, és jó alapot szolgáltatnak a rákkal kapcsolatos egészségnevelés számára.

1. táblázat | Európai Rákellenes Kódex: A rákmegelőzés 12 pontja

1. Ne dohányozzék! Ne fogyasszon semmiféle dohányterméket!

2. Otthonát, munkahelyét tegye „dohányzásmentes övezetté”!

3. Óvakodjon az elhízástól! Gondoskodjék egészséges testsúlyáról!

4. Iktassa napirendjébe a szabadidős mozgást! Minél kevesebb időt töltsön ülve!

5. Táplálkozzék egészségesen! Egyen mindennap friss gyümölcsöt, zöldséget! Vörös és feldolgozott húsokat mértékkel fogyasszon! Tartózkodjon a zsíros és a túlsózott ételektől, cukrozott italoktól!

6. Tartson mértéket az alkoholos italok fogyasztásában!

7. Kerülje a túlzott napozást, a leégést, a szoláriumot!

8. Munkahelyén tartsa be a munkavédelmi szabályokat! Ismerje és kerülje a rákot okozó anyagokat!

9. Óvakodjék az ionizáló sugárzás károsító hatásától!

10. Az anyák a szoptatással csökkenthetik az emlőrák kockázatát. Nők számára a csontritkulás hormonpótló kezelése kockázatos lehet.

11. Igényelje 12. életévét betöltött leánygyermeke számára a térítésmentes HPV elleni védőoltást!

12. Fogadja el a meghívást, és vegyen részt szervezett emlőszürésen, méhnyakszürésen és vastagbélszűrésen (utóbbi esetében férfiak és nők egyaránt)! Az 50 év feletti férfiak gondoljanak prosztatájuk egészségére! 
A felhasznált bizonyítékok forrása részben az International Agency for Research on Cancer (IARC) 40 éven át folytatott és publikált "IARC Monographs on the Evaluation on Carcinogenic Risk for Human" elnevezésű kutatási tevékenysége volt, amelyet a National Cancer Institute 2011-ben közleményben foglalt össze [13], részben a World Cancer Research Fund/American Institute for Cancer Research (WCRF/AICR) tárgyban felhasznált kutatási beszámolói [14].

\section{Ajánlások: 12 lehetőség, hogy csökkentse a rák kialakulásának kockázatát}

\section{Ne dobányozzék!}

Annak ellenére, hogy a dohányzás ártalmasságára már régen felfigyeltek, meggyőző bizonyítékkal csak az 1950-es években, Sir Richard Doll oxfordi epidemiológusnak a dohányzó és nem dohányzó angol orvosok körében végzett összehasonlító vizsgálatának köszönhetően rendelkezünk [15]. Ma már senki nem vitatja, hogy a dohányzás (mindenekfelett a cigarettázás) az egészség „első számú közellensége”, önmagában a legártalmasabb, de megelőzhető halálok. Az összes rákhalálozás mintegy 30\%-át, a férfiak tüdőrákjának 91\%-át, a nők tüdőrákjának 77\%-át a dohányzás okozza, ám oki szerepe van számos más szerv, úgymint a szájüreg, gége, nyelöcső, hasnyálmirigy, húgyhólyag és kofaktorként a gyomor, vastagbél, máj, méhnyak daganatainak létrejöttében [5]. Emellett számos más idült, nem fertőző betegség, úgymint a szív- és érbetegségek, idült légúti betegségek, gyomor- és nyombélfekély stb. létrejötte is a dohányzás rovására írható. Világszerte 6 másodpercenként meghal valaki a dohányzás ártalmai következtében [16].

Hazánkban a dohányzás helyzete különösen súlyos. Az „Európai lakossági egészségfelmérés - Magyarország 2009" adatai szerint [17] a 15 éves és idősebb lakosság csaknem harmada, több mint 2,5 millió ember dohányzik, többségük napi rendszerességgel. Mellettük még további másfél millióan vannak azok, akik valaha dohányoztak, de már leszoktak, tehát összességében négymillió felnőttet érint személyesen a dohányzás. Magyarország a rendszeres dohányosok arányát tekintve a vizsgált tizenhárom ország között a negyedik. Ez az „előkelő” helyezés elsősorban a nők körében tapasztalható magas dohányzási gyakoriságnak tulajdonítható. A férfiak ma még többen dohányoznak, mint a nők, ám a nők körében a dohányzás évek óta emelkedőben van [18]. (Ez már tükröződik a nők tüdőrák-halálozásának emelkedésében: a nők daganatos halálokai között az első helyre került, megelőzve a vastagbél- és emlőrákot.) Ez nyugtalanító jelenség, mert a tapasztalat szerint a dohányzás prevalenciájának csúcsát három-négy évtizeddel követi a dohányzással összefüggő halálozási értékek csúcsa.

A dohányzás egészségkárosító hatása arányos a naponta elszívott cigaretták számával, azok nikotin- és kátrány- tartalmával. Mindazonáltal a „kevés is sok”, azaz nem mentes a káros hatásoktól a csak „mérsékelten” dohányzó sem [19]. A füst nélküli dohányzás számos formája nem kevésbé ártalmas [20].

Az ideális cél: meggátolni, hogy a fiatal fiúk és lányok rászokjanak a dohányzásra, ám a leszoktatás is haszonnal jár. Epidemiológiai adatok igazolják, hogy a dohányzás abbahagyása után évről évre csökken az egészségkárosodás kockázata [21]. Doll és munkatársainak angol orvosok körében végzett vizsgálatai 50 éves követési idő után azt mutatták, hogy a dohányzást 30 éves kor előtt abbahagyó korábbi dohányosok életkilátásai nem rosszabbak, mint a nem dohányzóké [22]. A dohányzás mérséklése sem haszontalan, de eredmény csak a teljes elhagyásától várható [23]. Az egyre népszerúbb e-cigaretta, amelyet a leszoktatás „segédeszközeként” használnak, úgy tünik kevésbé ártalmas hagyományos társainál; hatásának megítélésére még nem rendelkezünk elegendő epidemiológiai adattal [24].

A magyar kormány csatlakozott a WHO Dohányzásellenőrzési Keretegyezményéhez, és több intézkedést hozott a dohányzás visszaszorítására. Többek között 2012. január óta tilos a szórakozóhelyek zárt légterében rágyújtani, 2013 júliusától pedig csak a nemzeti dohányboltokban lehet cigarettát vásárolni. A lépések kiemelt célja a fiatalok dohányzásának visszaszorítása. Esettanulmányok szerint a dohányzók számában egyelőre nem látszik lényeges csökkenés, az illegális dohányforgalmazás pedig nem megítélhető [25].

\section{Tegye otthonát, munkabelyét „dohányzásmentes övezetté”!}

A passzív dohányzást, azaz más, környezetünkben lévő "aktív" dohányzó személy által kifújt dohányfüst akaratlan belélegzését nevezik „second hand dohányzásnak” (SHS), „környezeti dohányzásnak” (ETS). A passzív dohányzás ártalmasságára az első bizonyítékot Hirayama japán kutató szolgáltatta: dohányzó férfiak nem dohányzó özvegyének, valamint nem dohányzó férfiak nem dohányzó özvegyének csoportjait hasonlította össze, és az első csoportban a tüdőrák előfordulását jelentősen magasabbnak találta [26]. Azóta - a sokasodó epidemiológiai bizonyítékok alapján - a passzív dohányzás egészségkárosító hatása bizonyítottnak tekinthető. Eszerint a passzív dohányzás következményeként növekszik a szívbetegségek, valamint a tüdő- és orrüregi rákok okozta halálesetek száma. Különösen veszélyes a terhesség alatti dohányzás, amelynek következményeként gyakoribb a magzati fejlődés visszamaradása, a magzati halálozás, vetélés, koraszülés és a szülés körüli halálozás [27].

Becslések szerint világszerte a felnőtt lakosság harmada passzív dohányos. A nem dohányzók többsége saját otthonában, munkahelyén, vendéglőkben vagy gépkocsiban részesül mások dohányfüstjéból [28]. 
Magyarországon több mint tíz éve létezik a „nemdohányzók védelméről” szóló jogszabály, amelyet a kormány 2011-ben nyomatékosított (2011. évi XCLI. törvény).

\section{3. Óvakodjék az elhizástól!}

A testsúlyt az energiabevitel és energiafelhasználás egyensúlya szabályozza: ha a bevitel meghaladja a felhasználást, súlytöbblet, túlsúlyosság, sôt elhízás következik be. Az elhízás mértékét az úgynevezett testtömegindex kiszámításával (body mass index - BMI) jellemzik, amely arányszám a testmagassághoz viszonyított testtömeget jelzi: a kilogrammban mért testsúlyt osztják a méterben kifejezett testmagasság négyzetével: testtömegindex = testtömeg $(\mathrm{kg}) /$ testmagasság $\left(\mathrm{m}^{2}\right)$.

A klinikai gyakorlatban 20 és 60 év között a 25 körüli BMI-értéket tartják elfogadhatónak. A 27 feletti érték túlsúlyosságot jelent, a 30 feletti értéket már elhízásnak, az egészségre kockázatot jelentő tényezőnek tekintik. A túlsúlyosság és kövérség között nem éles az átmenet: egy határon túl az elhízás önmagában is kockázati tényezőnek minősíthető kóros állapot. Azon túl, hogy a kövér ember élcelődések célpontja, önbizalomvesztéssel jár, gátolja a testmozgást, rontja az állóképességet, tehát jelentős lelki tehertétel.

Hazánkban, a lakossági egészségfelmérés eredményei szerint, a 15 év feletti lakosság több mint felének (53,7\%) a kívánatosnál magasabb a testtömege, minden ötödik felnőtt pedig egyenesen elhízott. Ez azt jelenti, hogy összességében csaknem 4,5 millió felnőttnek lenne érdemes elkezdeni fogyókúrázni. Az önbevalláson alapuló értékek szerint a nők körében valamivel kevesebb az elhízottak, illetve a túlsúlyosak aránya; mindkét kategóriában a férfiak vezetnek [17]. A táplálkozási szokások kialakulásában a családnak és a gyermek közvetlen környezetének döntő szerepe van. A túlsúlyos gyerekek és serdülők száma egyre nő. A kövér gyermekek nagy valószínűséggel felnőttkorukban is kövérek maradnak [29].

A túlsúlyosság vagy elhízás - többnyire hormonális mechanizmus révén - számos daganatra hajlamosít, ezek: menopauza utáni emlőrák, nyelőcsőrák, vastagbélrák, epehólyagrák, hasnyálmirigyrák, a méhnyálkahártya, petefészek rákja, de fokozott kockázatot jelent a vese, prosztata agresszív rákjának kialakulása szempontjából is. Becslések szerint az elhízás minden ötödik rák keletkezésében szerepet játszik [30, 31]. Az elhízás fokozott kockázatot jelent a szív- és érbetegségek és a nem inzulinfüggő cukorbetegség kialakulására is.

\section{Iktassa napirendjébe a szabadidős mozgást!}

A testmozgás a preventív egészség-magatartási tényezők közé tartozik, azaz a rendszeres fizikai aktivitás csökkenti bizonyos betegségek bekövetkeztének kockázatát. A fizikai tevékenység összetett magatartásforma, amelyet „energiafelhasználással járó, izomerővel végrehajtott testmozgás"-ként határoznak meg [32]. Intenzitásának mértékéül az anyagcsere alapszintjét meghaladó energiafelhasználást tekintik. Adott személy akkor éri el teljesítőképessége maximumát, ha „elfogy a levegője”, „liheg”, azaz már nem képes folyamatosan, csak szapora és mély légvételek által megszakítva beszélni. A rendszeres fizikai aktivitás növeli a munkavégző képességet, edzettséget és állóképességet, egyszóval „fittséget” eredményez. (Azért használjuk a „szabadidős mozgás” elnevezést, mert a munkavégzéssel, közlekedéssel járó mozgás kívül esik a megelőzés célkitűzésein.) Az ajánlások a testgyakorlás intenzitását, gyakoriságát és rendszerességét tartják fontosnak [33]. A választott mozgásforma lehet séta, úszás, kerékpározás vagy futás. A WHO definíciói alapján megfelelő fizikai aktivitást végez az a személy, akinek esetében az intenzív testmozgásra fordított heti időtartam kétszerese, valamint a gyaloglásra és a mérsékelt testmozgásra fordított heti időtartam összege legalább 150 perc; mérsékelt testmozgást végez az, akinél az említett időtartam ennél kevesebb; egyáltalán nem mozog az, akinél az időtartam egyenlő a nullával [17]. Heti 3-5 alkalommal ajánlatos testedzést végezni, esetenként mintegy 25-60 percig; ez három szakaszból álljon: bemelegítés (5-10 perc), terhelés (15-40 perc) és levezetés (5-10 perc).

A szabadidős testmozgás hiánya, avagy az ülő életmód számos betegség, úgymint a szív- és érbetegségek, különösen a koszorúér-betegség és az agyvérzés, magas vérnyomás, a 2-es típusú (nem inzulinfüggő) cukorbetegség, a csontritkulás, valamint egyes daganatos betegségek, úgymint a végbél-, emlő- és méhtestrák keletkezésére jelent kockázati tényezőt [34]. Ugyanakkor a fizikai aktivitás egyre nagyobb hangsúlyt kap mint a megelőzés eszköze: mérsékli a vastagbélrák és az emlőrák kockázatát, de adatok szólnak a prosztata, tüdő és a méhtest rákja és a fizikai aktivitás közötti kapcsolatról is [35]. A rendszeres fizikai aktivitás kedvezően hat a rákbetegek túlélésére is [36].

A testmozgás - a fizikai jóllét mellett - a mentális egészség fenntartásában is nagy szerepet játszik. A testmozgás hiánya természetesen hozzájárulhat a túlsúlyossághoz is. A már kialakult súlyfelesleg leküzdésében ezért a diéta mellett a mozgásnak is nagy szerep juthat. Sajnos, ezt az ajánlást kevesen teljesítik. Az ülő életformát (beleértve a rendszeres autóhasználatot is) újabban a rák független kockázati tényezőjének tekintik. Az Európai Lakossági Egészségfelmérés szerint a felnőtt magyar lakosság fele egyáltalán nem végez intenzív testmozgást, harmada mérsékelt testmozgást végez, ötöde pedig nem gyalogol egyfolytában még napi tíz percen keresztül sem [17].

\section{Táplálkozzék egészségesen!}

Epidemiológiai bizonyítékok szerint az életmóddal öszszefüggő kockázati tényezők között étrendünknek, táplálkozási szokásainknak szoros kapcsolata van a leggya- 
koribb nem fertőző betegségek létrejöttével. Ezért a hagyományos „nyugati étrend” hibáztatható. A mértéken felüli zsírbevitelnek, különösen a telített zsírsavaknak, a hozzáadott cukornak, sónak, valamint a komplex szénhidrátok és rostok alacsony bevitelének igazolt szerepe van a vastag- és végbélrák, az emlőrák, prosztatarák, méhtestrák és petefészekrák keletkezésében. A túlzott energiabevitel túlsúlyosságot, elhízást okozva hat károsan (különösen, ha mozgásszegény életvitellel társul). Hozzájárulnak a szív- és érbetegségek és osteoporosis kialakulásához is.

Egyes tanulmányok a táplálkozási tényezőket teszik felelőssé a daganatos halálozás mintegy harmadáért [4], hangsúlyozva, hogy megbízható bizonyítékok hiányában megállapításuk csupán becslés jellegú.

A fokozott zöldség- és gyümölcsfogyasztás az egészséges táplálkozás legfontosabb eleme, mert viszonylag alacsony energia-, zsír- és szénhidráttartalmukkal szemben jelentős vitamin-, ásványianyag- és antioxidáns-tartalmuk révén szerepet játszanak számos betegség kockázatának csökkentésében. Magas élelmirost-tartalmuk elősegíti a megfelelő bélmúködést, teltségérzetet biztosít, és jótékonyan befolyásolja szervezetünk zsír- és szénhidrát-anyagcseréjét. Magas víztartalmuknak köszönhetően hozzájárulnak a szervezet folyadékháztartásának egyensúlyához [37, 38]. Vannak a zöldség-gyümölcs fogyasztás rákhalálozást mérséklő hatását cáfoló adatok [39], ezek valóságtartalmát azonban módszertani oldalról kérdőjelezték meg [40]. Ideálisnak tartható a „mediterrán diéta", amely sok zöldséget, gyümölcsöt, gabonapelyhet, telítetlen zsírsavat jelentő olívaolajat, halat tartalmaz (egy kevés vörös borral) [41]. Ez az étrend mérsékli mind a rák, mind a szív- és érbetegségek kockázatát [42].

\section{Tartson mértéket az alkoholfogyasztásban!}

$\mathrm{Az}$ alkoholtartalmú italok élvezete szorongást oldó, a hangulatot kedvezően befolyásoló hatásuk miatt világszerte elterjedt szokás. Mértékletes fogyasztásuk a társadalmi normákkal nem ütköző, elfogadott, sőt egyes helyzetekben társadalmilag elvárt cselekvés. A bizonyos mértéket meghaladó, rendszeres alkoholfogyasztás azonban káros hatással van nemcsak a testi egészségre, hanem az emberi személyiségre is. Az alkohol függőséget, fogyasztására irányuló ellenállhatatlan késztetést okoz. Az alkohol okozta problémák összességükben nemcsak népegészségügyi, hanem társadalmi méretü$\mathrm{ek}$ is.

$\mathrm{Az}$ alkoholfogyasztás egészségkárosító hatása szempontjából gyakran nehéz határt vonni a sör-, bor- vagy pálinkafogyasztás még normális, elfogadható mértéke és az önkárosító magatartás között. Megkülönböztetnek egészségkárosodást még nem okozó, de annak kockázatát hordozó veszélyes, valamint a személyiség integritását, testi vagy lelki károsodást okozó ártalmas alkoholfogyasztást. „Nagyivónak” nevezik a hosszú időn át, rendszeresen, káros mennyiségű alkoholt fogyasztókat.
Az alkoholfogyasztás és a rákkeletkezés közötti összefüggést adatok tömege bizonyítja [43]. Az alkohol a rák kockázati tényezőinek egy különálló csoportját jelenti, amely az összes rákeset 2-4\%-áért felelős [44]; más becslések szerint a férfiak rákjának 10\%-a, a nők rákjának 3\%-a írható az alkohol rovására.

$\mathrm{Az}$ alkohol káros hatására vezethető vissza mindenekelőtt a szájüreg, garat, gége és nyelőcső rákjainak zöme; ezek keletkezésében az alkohol és dohányzás hatása egymással összeszorzódó mértékben érvényesül [45]. Az alkohol az elsődleges májrák kockázati tényezője [46]. Növeli az emlőrák keletkezésének kockázatát még mérsékelt fogyasztás esetén is [47]. Hasonlóan, növeli a vastag- és végbélrák kockázatát is [48]. Ellentmondásos a hasnyálmirigyrák keletkezésében játszott szerepe; a túlzott alkoholizálás a hasnyálmirigy-gyulladás egyik fó oka, amely viszont hajlamosít rákkeletkezésre [49].

Tartózkodjanak az alkoholfogyasztástól a gyermekek, tinédzserek és a terhes nők, a gépkocsit vezetők és gépkezelők, továbbá mindazok, akik figyelemösszpontosítást igénylő munkát végeznek. Azok, akik úgy érzik, hogy nem tudnak megállni egy-két pohárnál, valamint azok, akiknek egyszer már sikerült kigyógyulni az alkoholbetegségből.

Magyarországon az alkoholtartalmú italok vásárlása, így feltehetően fogyasztása is, európai összehasonlításban magas.

\section{Kerülje a túlzott napozást, a leégést, a szoláriumot; különösen gyermekeit óvja!}

Az ibolyántúli vagy ultraibolya (UV) sugárzás a színkép láthatatlan, 160-400 nm hullámhosszúságú tartománya, amely további három, különböző biológiai hatású tartományra oszlik. Természetes forrása a napfény. Az UV-C sugárzást teljesen, az UV-B sugárzást részben kiszúri a napjainkban sokat emlegetett „ózonpajzs”, amelynek elvékonyodásával azonban az ózonréteg csökkenő védőhatása, ezért az ibolyántúli sugárzás egészségkárosító hatása fokozott figyelmet érdemel. Mesterséges forrásai, különösen az UV-A-t kibocsátó szoláriumok a „napfényiparban" terjedőben vannak.

Az UV-B, amelyben a napfény leginkább bővelkedik, szemkárosodást, valamint heveny és idült bőrkárosodást okoz [50]. A bőr bazális sejtjeiből kiinduló basalioma, valamint a bőr laphámrákja közel sem jelent olyan súlyos problémát, mint a hám és az irha határán lévő, festéktartalmú melanocytákból kiinduló melanoma malignum. A legnagyobb kockázatot a szakaszosan, időról időre, de intenzíven érvényesülő károsító hatás jelenti, amelynek az általában zárt helyen dolgozó, de szabadidejükben a napozás örömeit mértéktelenül élvező nyaralók vannak leginkább kitéve. Az akut bőrkárosodás a leégés: bőrpírral, duzzanattal, hólyagképződéssel és hámlással jár. A melanomakeletkezés kockázata arányos a - különösen fiatalkorban - elszenvedett leégési epizódok számával. 
A napozási szokásokat nagyban befolyásolja a divat, hiszen a társadalom bizonyos körei a napbarnított bőrt pozitív „státuszszimbólumnak” tekintik. Ezzel a divattal függ össze a szolárium használatának terjedő szokása is, amely - bár az UV-A sugárzást kevésbé tartják károsnak - elősegíti a bőr öregedését.

A napfürdőzés nemcsak élvezet, hanem - mérséklettel - hasznos is (D-vitamin-képződés), teljes kiiktatása nem lehet a megelőzés célja. A népesség felvilágosítása a túlzásba vitt napozás ártalmairól az egészségnevelés feladata [51]. Ebben kitüntetett szerepük van az alapellátásban dolgozóknak [52]. Hatásos védekezést biztosít a kereskedelmi forgalomban kapható napozókrémek használata, amelyek kiszürik a leginkább káros ultraibolya sugarakat. A tubuson feltüntetett szám $(\mathrm{SPF}=$ skin protective factor) azt fejezi ki, hogy használója mennyi időt tölthet el napozással anélkül, hogy bőre károsodna. Példaként, az „SPF 10” jelzésű krémet használók tízszer hosszabb időt tölthetnek bőrkárosodás nélkül napozással, mintha nem használnának védőkrémet [53].

\section{Ismerje és kerïlje a rákot okozó anyagokat! Tartsa be a munkavédelmi szabályokat!}

A WHO/IARC a „Monographs on the Evaluation of Carcinogenic Risks to Humans" elnevezésű programja keretében 107, a munkahelyeken megtalálható, munkafolyamatokkal összefüggő kémiai anyagról, vegyületről, ipari termékről, ipari munkafolyamatról és ipari szennyeződésekrôl állapította meg, hogy karcinogén természetú, azaz a rák keletkezése szempontjából kockázati tényezőnek tekinthető. Más források a munkahelyeken előforduló, potenciálisan rákkeltő anyagok számát ennél is többre becsülik [54]. A munkahelyi ártalmak közül az azbesztet találták a legártalmasabbnak, ezt követi a szilícium-dioxid, a dízelmotorok égésterméke, a benzén, a kadmium, az etilén-oxid, a benzpirén. A foglalkozások közül az építőipar, olajipar, bányaipar, fémipar és a festőipar a legártalmasabb [55].

A leggyakoribb „foglalkozási rák” a tüdőrák, mesothelioma és a hólyagrák. A tüdőrák miatti halálozás mintegy 10\%-át okozzák foglalkozási rákkeltők [56].

Doll és Peto mintegy 4\%-ra becsülte a „foglalkozási rákhalálozás" gyakoriságát úgy, hogy a bizonytalansági tényezők valószínúségét $2 \%$ és $8 \%$ közöttinek vélték [4]. A 40 évvel későbbi utánvizsgálók a becslést helyénvalónak találták [5].

A foglalkozási rákok nagy többsége a káros anyagok forgalomból kivonásával, más anyaggal történő helyettesítéssel, szellőztetéssel megelőzhető. Fontos a munkavédelmi szabályok betartása!

Szokás „környezeti rákkeltő” tényezőkről beszélni [57]. Ezeken általában a „külső”, azaz fizikai környezetben lévő rákkeltő tényezőket értik, úgymint a levegő-, víz- és talajszennyeződést, a radon okozta ionizáló sugárzást és a természetes háttérsugárzást is. Tágabb értelemben „külső” kockázati tényező a passzív dohányzás és az ultraibolya sugárzás is, amelyről másutt, az életmóddal összefüggő megelőzésnél esett szó.

\section{9. Óvakodjék az ionizáló sugárzás kárositó batásától!}

Ionizációs sugárzásnak mindig és mindenhol ki vagyunk téve. Ebből a világürből érkező és testünk atomjaiból származó természetes sugárzásból évente nagyságrendileg $1 \mathrm{mSv}$ dózist kapunk (az SI-rendszerben az ionizáló sugárzás biológiai, egészségkárosító hatásának mérésére használt, ajánlójáról, R. M. Sievertről elnevezett mértékegység). Életmódunknak köszönhetően létrehoztunk extra sugárforrásokat, mint az orvosi röntgensugárzás [58]; ezek károsító hatását sugárvédelmi elő́rások igyekeznek a lehető legalacsonyabb szinten tartani. Ilyen sugárforrás saját házunk is; lakásunkban az ionizációs sugárzást a radon sugárzása okozza. (A radon természetesen előforduló radioaktív gáz, amely a talajban és - egyebek mellett - a házak alapozásában használt kőzetek zárványaiban fordulhat elő. Egyik lehetséges forrása a házon belüli levegőszennyeződésnek; bomlástermékeinek szerepe van a tüdőrák létrejöttében [59].)

\section{A szoptatás csökkenti az emlörák kialakulásának valószinüségét. A csontritkulás hormonpótló kezelése kockázatos lehet a nök számára}

Megfigyelések és egymásnak ellentmondó statisztikai adatok szerint, nem tudni miért, a szoptatásnak mérsékelt védőhatása van az emlőrák keletkezésével szemben; ez a hatás különösen fiatalabb korban figyelhető meg. A védőhatás kifejezettebb, ha az asszonyok hosszabb időn át szoptatnak [60]. A szoptatás gyorsítja a szülés előtti testsúly visszanyerését [11].

Meggyőző bizonyítékok tanúsítják, hogy a 60 év alatti nők csontritkulásának kezeléseként alkalmazott hormonpótló kezelés, amely fokozza a csont sûrüségét és csökkenti a csonttörés kockázatát, mérsékli a tüneteket, ám kismértékben növeli az emlőrák, méhtestrák és petefészekrák keletkezésének kockázatát [61]. Más, lehetséges mellékhatásai miatt (agyvérzés, mélyvénás trombózis) a kezelést a lehető legkisebb, még hatásos dózisban, a lehető legrövidebb ideig ajánlják alkalmazni; a kezelés csak a várható haszonról és a lehetséges kockázatokról való tájékoztatás után, beleegyezés birtokában kezdhető meg [62].

\section{Igényelje 12. életévét betöltött leánygyermeke számára a téritésmentes HPV elleni védőoltást!}

Ismeretes, hogy a humán papillomavírus (HPV) a méhnyakrák szükséges, de önmagában nem elégséges okozója [63]. A HPV-fertőzés gyakori. Többsége spontán 
gyógyul, csak permanens, azaz az éveken át fennálló fertőzés vezet rákkeletkezéshez. (A HP-vírus a méhnyakrák mellett ritkán vulva-, hüvely-, anus-, penis- és szájüregi rákot is okozhat.) A HPV elleni védőoltás - a szexuális élet megkezdése előtt alkalmazva - védelmet nyújt a vírus leggyakrabban daganatot okozó (de nem mindegyik) típusával szemben [64]. Ez utóbbiak szintén a betegség okozói lehetnek, ezért az oltás a szervezett szürővizsgálaton való részvételt nem teszi feleslegessé.

Számos európai ország gyakorlatát követve, a magyar kormány úgy rendelkezett, hogy a HPV elleni oltás kapjon helyet a 12. életévet betöltött lányok iskolai oltásai sorában. A megkérdezett szülők több mint $80 \%$-a igényelte a megajánlott ingyenes oltást. Azok a 13-26 év közötti nők is igényelhetik, akik korábban nem részesültek oltásban.

Ha egy személy megkapta az oltást, akkor immunrendszere felismeri a támadó vírusokat, és olyan ellenanyagokat állít elő, amelyek megpróbálják elpusztítani vagy hatástalanítani azokat.

A fertőzések szerepének megítélése a rosszindulatú daganatok kialakulásában az epidemiológia ma még mozgásban lévő területe. Már korábban ismert volt, hogy a hepatitis B-vírus májrákot okoz. Ismert volt az Epstein-Barr-vírus és a Burkitt-lymphoma kapcsolata is. Doll és Peto még azelőtt becsülte meg a fertőzések szerepét, mielőtt a HPV szerepe a méhnyakrák, a hepatitis C-vírus a májrák vagy a Helicobacter pylori a gyomorrák kialakulásában ismertté vált volna [4]; ők legalább 1\%-ra becsülték a fertőző ágensek szerepét, ám a lehetséges felső határt 10\%-ban jelölték meg, teret engedve újabb öszszefüggések felismerésének. A legfrissebb epidemiológiai felmérések (példaként a HIV szerepének ismeretében) a fejlett országokban 23\%-ra, a fejlődő országokban 27\%ra becsülik a fertőzéssel összefüggő daganatok részesedését [65]. Csecsemők, gyermekek és serdülők hepatitis B elleni oltása szerepel az oltási naptárban.

\section{Ha meghivást kap, vegyen részt szervezett emlöszürésen, méhnyakszürésen és vastagbélszürésen (utóbbi esetében férfiak és nők egyaránt)! Az 50 év feletti férfiak gondoljanak prosztatájuk egészségére!}

A szűrővizsgálatok a rák mielőbbi felismerését és kezelését célozzák. Egészséges vagy önmagukat egészségesnek tartó személyek időről időre megismételt vizsgálata abból a célból, hogy egyes daganatos megbetegedések fennállásának valószínűségét kizárja vagy fennállását valószínúsítse. A nem negatív szürővizsgálati lelet mielőbbi tisztázó klinikai diagnosztikus vizsgálatot indokol. A szûrővizsgálattal felismert rákmegelőző állapot vagy rák korábban kerül orvosi kezelésre, mint szűrővvizsgálat nélkül került volna, ezáltal a gyógykezelés eredményesebb. A szűrővizsgálat eredményessége a célbetegségből származó halálozás mérséklésében mutatkozik meg.
Alkalomszerü és szervezett szűrővizsgálatot különböztetünk meg:

- Az alkalomszerú szúrővizsgálat az orvosi tevékenység része: az „onkológiai éberség” jegyében a rejtett betegség felismerését szolgáló vizsgálati módszert a páciens kérésére, vagy a mindennapos, bármely más célból létrejött orvos-beteg találkozás keretében végzik el, vagy javasolják elvégeztetését.

- A szervezett szúrôvizsgálatot a szolgáltató, azaz az egészségügyi ellátórendszer kezdeményezi és finanszírozza, szakmailag indokolt időközökben megismétli. A népesség nagy, az életkor alapján veszélyeztetettnek minősülő hányadára terjed ki, akiket személy szerint hívnak meg a vizsgálatra. A meghívás az Országos Egészségbiztosítási Pénztár (OEP) adatbázisa alapján készült lakosságlista felhasználásával, névre szóló, személyes hangvételü levélben történik, amelyben megjelölik a vizsgálat helyét és javasolt idejét. A vizsgálaton meg nem jelenőket emlékeztető levéllel keresik fel.

A kialakult szakmai közmegegyezés szerint szervezett szúrés csakis azokban a szúrővizsgálati módozatokban kezdeményezhető, amelyek eredményessége a célbetegségból származó halálozásnak a céllakosságban mért mérséklődésével bizonyítást nyert. Ezek:

- a 25-65 év közötti nők háromévenkénti sejtvizsgálata (citológia) a méhnyakrák és megelőző állapotainak felismerése céljából;

- a 45-65 év közötti nők emlőinek kétévenkénti lágyrész-röntgenvizsgálata (mammográfia) az emlőrák korai felismerése érdekében;

- az 50-70 év közötti férfiak és nók esetében a székletbeli rejtett vér kimutatását célzó laboratóriumi vizsgálat a vastag- és végbélrák kimutatására.

Ajánlatos részt venni szürővizsgálaton minden olyan esetben, amikor a szűréstől várható haszon, azaz a halálozás mérséklése bizonyítottan nagyobb, mint az okozható kár (ilyen kár például a túldiagnosztizálás: a vizsgálat rákot valószínúsít, jóllehet valójában nincs rák, és a következményes túlkezelés) [66].

$\mathrm{Az}$ eredményesség epidemiológiai bizonyítékával ez idő szerint nem rendelkező szûrőmódszert szervezett program keretében nem lehet végezni. Elvégzésük csak alkalomszerúen, a szakorvosi vizsgálat keretében bátorítható.

\section{Megbeszélés}

A sikeres rákmegelőzés alapja az egyének egészségtudatos életmódja, amelyet az egészségvédelem érdekeit szem előtt tartó kormánypolitika támogat.

$\mathrm{Az}$ életmód fogalmát nem szociológiai értelemben, hanem az egészség-betegség, a betegségkeletkezés és betegségmegelőzés összefüggésében határozzuk meg. Hétköznapi megközelítésben életmódnak nevezzük beidegzett szokásainkat, megszokott tevékenységünket, amelyek mindennapi életvitelünkre jellemzőek. Az életmód - a koncepció első megfogalmazója szerint - „az 
egészségre befolyással lévő személyes döntések halmazát jelenti, amelyre az egyénnek több-kevesebb befolyása van" [67]. Az Európai Rákellenes Kódex az egyének életmódjára, viselkedésére nézve megfogalmazott, személyes hangvételü tanácsokat ad. Azokat az egészségre hatással lévő személyes döntéseket kívánja befolyásolni, amelyek az egyének illetékességén, döntési kompetenciáján belül vannak. Mindenkinek személyes döntése ugyanis felvenni az egészségre káros szokásokat, vagy elhagyni azokat: feladni a dohányzást, mérsékelni az alkoholfogyasztást, az elhízást, egészséges mozgással felváltani a mozgásszegény életmódot, korlátozni a napfény élvezetét stb. A kódex az egyének összességét, a lakosságot az egészséges életmód kialakítására, az egészségre káros szokások, a rákkeletkezésre kockázatot jelentő „anyagok” elhagyására ösztönzi.

A kódex a személyre szóló egészségnevelés hatékony üzenethordozója. Az egészségnevelés - a WHO meghatározása szerint - „tudatosan létrehozott tanulási lehetőségek összessége, amelyek az egészségre és betegségre vonatkozó tudás bóvítésével segítik az egyént és a közösséget egészségük előmozdításában” [68]. Célja az egészségtudatos magatartás kialakítása, és az egészséggel öszszefüggő viselkedésmód kedvező befolyásolása. Az egyénnek ugyanis életmódja révén bizonyos határig módja van befolyásolni egészségi állapotát, amely visszahat az életmódra. Az egészség-magatartást természetesen demográfiai tényezők, az egyén életkora és neme, társadalmi-gazdasági helyzete is jelentősen befolyásolják.

Az egészségtudatos magatartás az egészségkultúrával rokon fogalom. Magába foglalja mindazokat a magatartási mintákat, cselekvéseket és szokásokat, amelyek hozzájárulnak az egészség fenntartásához. Annak tudatosodását jelenti, hogy az egészség érték, amelyért az egyén felelősséggel tartozik: az „egészségérték-gazdálkodás” az egyén önérdeke [69]. Olyan szemléletet és az abból következő életvitelt jelent, amely az egészség és az egészséges életmód követelményeit szem előtt tartja, és azokat tudatos döntéseiben érvényesíti. Akár úgy, hogy nemet mond a vonzó, de egészségkárosító „rossz szokásokra”, akár úgy, hogy új, az egészséget elősegítő szokásokat alakít ki. Az egészségkultúra része olyan magatartásformák elsajátítása is, amely az egészséget közvetlenül vagy közvetve veszélyeztető tényezőket elhárítja: igent mond a szürôvizsgálatra vagy védőoltásra szóló meghívásra. Az egészségnevelés feladata az ember egészségmagatartásának befolyásolása az egészségtudatos magatartás irányába.

Az egészség-magatartás változtatásának kérdéseivel számos társadalmi-lélektani elmélet és modell foglalkozik [70]. A magatartás-változást nem pillanatnyi történésnek, hanem folyamatnak tekintik, amely a „rossz szokáshoz" ragaszkodástól a változtatás szándékának érlelődésén át a fenntartott döntésig, a visszaesések sikeres korrekciójáig tart [71]. Az egyén magatartásának meghatározásában a motivációjának, akaraterejének és az önszabályozásnak kulcsszerepe van [71].
Ám mindez önmagában kevés. Az egyén életmóddöntésének vannak korlátai. Nem kisebbítve az egyén személyes döntéseinek szerepét saját életmódjának, szokásainak kialakításában - így felelősségét a következményes egészségkárosodásokért sem -, az egyén személyes felelőssége nem kizárólagos. Az egyén személyes életmóddöntéseire jelentős befolyással van társadalmi-gazdasági környezete, amelyben él, ideértve a társadalomra jellemző normák és értékek rendszerét is, amit a szociológusok „kulturális környezetnek” neveznek.

A kormányzattól elvárható, hogy a gazdasági prioritásokat összhangba hozza a népegészségügyi érdekekkel, és azokat a törvényalkotás és a jogszabályi befolyásolás eszközeivel szolgálja. Ilyenek a dohányzást, a passzív dohányzást és alkoholfogyasztást korlátozó, az egészséges táplálkozást elősegítő árpolitika, vám-, adó- és kereskedelmi intézkedések, reklámszabályozás, munkavédelmi és környezetvédelmi rendszabályok, amelyekre a közelmúlt kormánypolitikája számos jó példát szolgáltatott.

Az ingyenes HPV elleni oltás felkínálása és a szervezett szúrés lehetőségének megteremtése is kormányzati feladat, igénybevétele azonban személyfüggő. A hazai kormányzat létrehozta a szervezett szû́rés forrásigényes tárgyi és személyi feltételeit, a lehetőségek kihasználása azonban messze a kívánatos alatt marad. Ennek következményei megrázóak: a rákos megbetegedések előfordulása (morbiditás) „csupán” 4\%-kal, a rosszindulatú daganatok miatti halálozás már 42\%-kal magasabb az európai átlagnál, nyilvánvalóan a korai daganatfelismerést és korai kezelést szolgáló szűrési lehetőségek kihasználatlansága miatt [72].

\section{Következtetések}

Az Európai Rákellenes Kódex személyre szabott tanácsokat fogalmaz meg a betegséghez vezető kockázati tényezők lehetséges kiiktatásáról és a betegségek megelőzését szolgáló egészségügyi szolgáltatások elfogadásáról. A tanácsok megszívlelése jelentősen hozzájárulhat a rosszindulatú daganatok okozta betegségteher mérséklődéséhez, amelyet az egyének és a társadalom egésze ma még hordozni kénytelen. Az egészséggel kapcsolatos életmódváltozás különösen sürgető ma, és különösen az ifjabb korosztályok számára, akiknek életszemléletét és életvitelét a pillanatnyi örömforrások kimerítése jellemzi, homályban hagyva a jövớben várható előnyöket vagy éppen a fenyegető egészségkárosodásokat.

Az egészségkárosító életmód megváltoztatását kinekkinek magának kell megszenvednie. Mindazonáltal az egészségnevelés szócsöveinek, a médiának kötelessége felhívni a figyelmet az egészségkockázat forrásaira, az egészségügyi ellátórendszernek, az egészségügyi szolgáltató orvosoknak és nóvéreknek pedig támogatást nyújtania a változtatni szándékozó egyéneknek változtatási szándékuk sikerre viteléhez. Ennek eszköze lehet az Európai Rákellenes Kódex ismertté tétele minél szélesebb körben. 
A kódex értékét növeli, hogy a legnagyobb népegészségügyi súlyú - mind az egyénekre, mind a társadalom egészére a legnagyobb betegségterhet hárító, az idő előtti halálozásért legnagyobb mértékben okolható nem fertőző idült betegségek, így a szív- és érbetegségek, cukorbetegség és a rosszindulatú daganatos betegségek nagy hányadának kialakulásában közös kockázati tényezők játszanak szerepet. Eszerint a kardiológiai és onkológiai megelőzés elkülönítését csak didaktikai szempontok indokolják. Azok tehát, akik az életmóddal öszszefüggő kockázati tényezők mérséklésén fáradoznak, egyszerre szolgálják a keringési rendszer betegségeinek és a daganatos betegségek megelőzésének ügyét.

Anyagi támogatás: A közlemény megírása anyagi támogatásban nem részesült.

Szerzői munkamegosztás: D. L.: A közlemény elkészítője. C. Á.: Szöveggondozás. A cikk végleges változatát mindkét szerző elolvasta és jóváhagyta.

Érdekeltségek: A szerzőknek nincsenek a dolgozat témáját érintő érdekeltségeik.

\section{Irodalom}

[1] IARC: Latest world cancer statistics. Press Release $\mathrm{N}^{\circ} 223.12$ December 2013.

[2] Ferlay, J., Steliarova-Foucher, E., Lortet-Tieulent, J., et al.: Cancer incidence and mortality patterns in Europe: estimates for 40 countries in 2012. Eur. J. Cancer, 2013, 49(6), 1374-1403.

[3] Eurostat News Release, 179/2014 - 25 November 2014 http://ec.europa.eu/eurostat/documents/299552l/ 6131615/3-25112014-BP-EN/aab2c2d3-aed9-430a-a561el $188 \mathrm{~b} 8 \mathrm{ef} 49 \mathrm{~d} 8$

[4] Doll, R., Peto, R.: The causes of cancer: quantitative estimates of avoidable risk of cancer in the United States today. J. Natl. Cancer Inst., 1981, 66(6), 1192-1308.

[5] Blot, W. J., Tarone, R. E.: Doll and Peto's quantitative estimates of cancer risks: holding generally true for 35 years. J. Natl. Cancer Inst., 2015, 107(4), djv044

[6] Anand, P., Kunnumakara, A. B., Sundaram, C. V., et al.: Cancer is a preventable disease that requires major lifestyle changes. Pharm. Res., 2008, 25(9), 2097-2116.

[7] Parkin, D. M., Boyd, L., Walker, L. C.: The fraction of cancer attributable to lifestyle and environmental factors in the UK in 2010. Br. J. Cancer, 2011, 105(Suppl. 2), S77-S81.

[8] World Health Organization: Ottawa Charter for Health Promotion. Health Promotion, 1986, 1, iii-iv.

[9] Boyle, P., Veronesi, U., Tubiana, M., et al.: European School of Oncology Advisory report to the European Commission for the "Europe Against Cancer Programme": European Code Against Cancer. Eur. J. Cancer, 1995, 31A(9), 1395-1405.

[10] Boyle, P., Autier, P., Bartelink, H., et al.: European Code Against Cancer and scientific justification: third version. Ann. Oncol., 2003, 14(7), 973-1005.

[11] Schüz, J., Espina, C., Villain, P., et al.: European Code against Cancer 4th Edition: 12 ways to reduce cancer risk. Cancer Epidemiol., 2015, 39(Suppl. 1), S1-S10.

[12] Boyle, P., Eckhardt, S.: European Code against Cancer. [Európai Rákellenes Kódex.] Magy. Onkol., 1996, 40(2), 68-75. [Hungarian]
[13] Cogliano, V. J., Baan, R., Straif, K., et al.: Preventable exposures associated with human cancers. J. Natl. Cancer Inst., 2011, 103(24), 1827-1839.

[14] Romaguera, D., Vergnaud, A. C., Peeters, P. H.: Is concordance with World Cancer Research Fund/American Institute for Cancer Research guidelines for cancer prevention related to subsequent risk of cancer? Results from the EPIC study. Am. J. Clin. Nutr., 2012, 96(1), 150-163.

[15] Doll, R., Peto, R., Wheatley, K., et al.: Mortality in relation to smoking: 40 years' observations on male British doctors. BMJ, 1994, 309(6959), 901-911.

[16] World Health Organization: Global health risks: mortality and burden of disease attributable to selected major risks. WHO Press, Geneva, 2009.

[17] Hungarian Central Statistical Office: European Health Interview Survey 2009. [Európai lakossági egészségfelmérés 2009.] Központi Statisztikai Hivatal, Budapest, 2012. [Hungarian]

[18] Pirie, K., Peto, R., Reeves, G. K., et al., Million Women Study Collaborators: The 21 st century hazards of smoking and benefits of stopping: a prospective study of one million women in the UK. Lancet, 2013, 381(9861), 133-141.

[19] Bjartveit, K., Tverdal, A.: Health consequences of smoking 1-4 cigarettes per day. Tob. Control, 2005, 14(5), 315-320.

[20] Boffetta, P., Hecht, S., Gray, N., et al.: Smokeless tobacco and cancer. Lancet Oncol., 2008, 9(7), 667-675.

[21] Gandini, S., Botteri, E., Iodice, S., et al.: Tobacco smoking and cancer: a meta-analysis. Int. J. Cancer, 2008, 122(1), 155-164.

[22] Doll, R., Peto, R., Boreham, J., et al.: Mortality in relation to smoking: 50 years' observations on male British doctors. Br. Med. J., 2004, 328(7455), 1519.

[23] Gerber, Y., Myers, V., Goldbourt, U.: Smoking reduction at midlife and lifetime mortality risk in men: a prospective cohort study. Am. J. Epidemiol., 2012, 175(10), 1006-1012.

[24] Burstyn, I.: Peering through the mist: systematic review of what the chemistry of contaminants in electronic cigarettes tells us about health risks. Br. Med. J. Public Health, 2014, 14(1), 18.

[25] WHO: Tobacco control in practice: Article 8: Protection from exposure to tobacco smoke: the story of Hungary. WHO Regional Office for Europe, Copenhagen, 2014.

[26] Hirayama, T.: Cancer mortality in nonsmoking women with smoking husbands on a large-scale cohort study in Japan. Prev. Med., 1984, 13(6), 680-690.

[27] WHO Report on the Global Tobacco Epidemic, 2009. Imple menting smoke-free environments. WHO, Geneva, 2009.

[28] Semple, S., Apsley, A., Galea, K. S., et al.: Secondhand smoke in cars: assessing children's potential exposure during typical journey conditions. Tob. Control, 2012, 21(6), 578-583.

[29] Cali, A. M., Caprio, S.: Obesity in children and adolescents. J. Clin. Endocrinol. Metab., 2008, 93(11 Suppl. 1), S31-S36.

[30] Williams, S. C.: Link between obesity and cancer. Proc. Natl. Acad. Sci., 2013, 110(22), 8753-8754.

[31] Bhaskaran, K., Douglas, I., Forbes, H., et al.: Body mass index and risk of 22 specific cancers: a population-based cohort study of 5.24 million UK adults. Lancet, 2014, 384(9945), 755-765.

[32] Powell, K. E., Thompson, P. D., Caspersen, C. J., et al.: Physical activity and the incidence of coronary heart disease. Annu. Rev. Public Health, 1987, 8(1), 253-287.

[33] Slattery, M. L.: Physical activity and colorectal cancer. Sports Med., 2004, 34(4), 239-252.

[34] Fair, A. M., Montgomery, K.: Energy balance, physical activity, and cancer risk. Methods Mol. Biol., 2009, 472, 57-88.

[35] IARC Handbooks of Cancer Prevention. Vol. 6. Weight Control and Physical Activity. IARC, Lyon, 2002.

[36] Holmes, M. D., Chen, W. Ү., Feskanich, D., et al.: Physical activity and survival after breast cancer diagnosis. JAMA, 2005, 293(20), 2479-2486. 
[37] Leenders, M., Boshuizen, H. C., Ferrari, P., et al.: Fruit and vegetable intake and cause-specific mortality in the EPIC study. Eur. J. Epidemiol., 2014, 29(9), 639-652.

[38] Wang, X., Ouyang, Y., Liu, J., et al.: Fruit and vegetable consumption and mortality from all causes, cardiovascular disease, and cancer: systematic review and dose-response meta-analysis of prospective cohort studies. BMJ, 2014, 349, g4490.

[39] Schatzkin, A., Kipnis, V.: Could exposure assessment problems give us wrong answers to nutrition and cancer questions? J. Natl. Cancer Inst., 2004, 96(21), 1564-1565.

[40] Hung, H. C., Joshipura, K. J., Jiang, R., et al.: Fruit and vegetable intake and risk of major chronic disease. J. Natl. Cancer Inst., 2004, 96(21), 1577-1584.

[41] Sofi, F., Abbate, R., Gensini, G. F.: Accruing evidence on benefits of adherence to the Mediterranean diet on health: an updated systematic review and meta-analysis. Am. J. Clin. Nutr., 2010, 92(5), 1189-1196.

[42] Giacosa, A., Barale, R., Bavaresco, L., et al.: Cancer prevention in Europe: the Mediterranean diet as a protective choice. Eur. J. Cancer Prev., 2013, 22(1), 90-95.

[43] IARC Working Group on the Evaluation of Carcinogenic Risks to Humans: Alcohol consumption and ethyl carbamate. IARC Monogr. Eval. Carcinog. Risks Hum., 2010, 96, 3-1383.

[44] Bagnardi, V., Rota, M., Botteri, E., et al.: Alcohol consumption and site-specific cancer risk: a comprehensive dose-response meta-analysis. Br. J. Cancer, 2015, 112(3), 580-593.

[45] Hashibe, M., Brennan, P., Chuang, S. C., et al.: Interaction between tobacco and alcohol use and the risk of head and neck cancer: pooled analysis in the International Head and Neck Cancer Epidemiology Consortium. Cancer Epidemiol. Biomarkers Prev., 2009, 18(2), 541-550.

[46] Grewal, P., Viswanathen, V. A.: Liver cancer and alcohol. Clin. Liver Dis., 2012, 16(4), 839-850.

[47] Allen, N. E., Beral, V., Casabonne, D., et al.: Moderate alcohol intake and cancer incidence in women. J. Natl. Cancer Inst., 2009, 101(5), 296-305.

[48] Fedirko, V., Tramacere, I., Bagnardi, V., et al.: Alcohol drinking and colorectal cancer risk: an overall and dose-response metaanalysis of published studies. Ann. Oncol., 2011, 22(9), 19581972.

[49] Ye, W., Lagergren, J., Weiderpass, E., et al.: Alcohol abuse and the risk of pancreatic cancer. Gut, 2002, 51(2), 236-239.

[50] Lea, C. S., Scotto, J. A., Buffler, P. A., et al.: Ambient UVB and melanoma risk in the United States: a case-control analysis. Ann. Epidemiol., 2007, 17(6), 447-453.

[51] Hughes, B. R., Altman, D. G., Newton, J. A.: Melanoma and skin cancer: evaluation of a health education programme for secondary schools. Br. J. Dermatol., 1993, 128(4), 412-417.

[52] Austoker, J.: Melanoma: prevention and early diagnosis. Br. Med. J., 1994, 308(6945), 1682-1686.

[53] Beauty and the beast [editorial]. Lancet Oncol., 2009, 10(9), 835.

[54] Rushton, L., Hutchings, S., Brown, T.: The burden of cancer et work: estimation as first step to prevention. Occup. Environ. Med., 2008, 65(12), 789-800.

[55] Lim, S. S., Vos, T., Flaxman, A. D., et al.: A comparative risk assesment of burden of disease and injury attributable to 67 risk fac- tors and risk factor clusters in 21 regions, 1990-2010: a systematic analysis for the Global Burden of Disease Study 2010. Lancet, 2012, 380(9859), 2224-2260.

[56] Olsson, A., Gustavsson, P., Zaridze, D., et al.: Lung cancer risk attributable to occupational exposures in a multicenter casecontrol study in Central and Eastern Europe. J. Occup. Environ. Med., 2011, 53(11), 1262-1267.

[57] Boffetta, P., Nyberg, F.: Contribution of environmental factors to cancer risk. Br. Med. Bull., 2003, 68(1), 71-94.

[58] Fazel, R., Krumbolcz, H. M., Wang, Y., et al.: Exposure to lowdose ionizing radiation from medical imaging procedures. N. Engl. J. Med., 2009, 361(9), 849-857.

[59] Darby, S., Hill, D., Auvinen, A., et al.: Radon in homes and risk of lung cancer: collaborative analysis of individual data from 13 European case-control studies. Br. Med. J., 2005, 330(7485), 223.

[60] Lipworth, L., Bailey, L. R., Trichopoulos, D.: History of breastfeeding in relation to breast cancer risk: a review of the epidemiologic literature. J. Natl. Cancer Inst., 2000, 92(4), 302-312.

[61] Beral, V., Reeves, G., Bull, D., et al.: Breast cancer risk in relation to the interval between menopause and starting hormone therapy. J. Natl. Cancer Inst., 201 1, 103(4), 296-305.

[62] Barrett-Connor, E., Stuenkel, C. A.: Hormone replacement therapy (HRT): risks and benefits. Int. J. Epidemiol., 2001, 30(3), 423-426.

[63] zur Hausen, H.: Papillomaviruses and cancer: from basic studies to clinical application. Nat. Rev. Cancer, 2002, 2(5), 342-350.

[64] Koiss, R., Siklós, P.: The relationship between human papilloma virus and cervical cancer HPV and cervical cancer. [A humán papillomavírus és a méhnyakrák kapcsolata.] LAM, 2010, 20(2), 96-102. [Hungarian]

[65] De Martel, C., Ferlay, J., Franceschi, S., et al.: Global burden of cancers attributable to infections in 2008: a review and synthetic analysis. Lancet Oncol., 2012, 13(6), 607-615.

[66] Von Karsa, L., Dean, P. B., Arrosi, S.: Opportunities and constrains for cancer screening. In: Wild, C., Steward, B. (eds.): World Cancer Report. IARC, Lyon, 2014.

[67] Lalonde, M.: New perspective on the health of Canadians. Department of Supply and Services, Ottawa, 1974.

[68] World Health Organization: Health Promotion Glossary. WHO, Geneva, 1998.

[69] Simon, T.: Meditation on health and its worth. [Elmélkedések az egészségről és annak értékéről.] Egészségtudomány, 2009, 53(1), 130-136. [Hungarian]

[70] Ashford, S., Edmunds, J., French, D. P.: What is the best way to change self-efficacy to promote lifestyle and recreational physical activity? A systematic review with meta-analysis. Br. J. Health Psychol., 2010, 15(2), 265-288.

[71] Jepson, R. G., Harris, F. M., Platt, S., et al.: The effectiveness of interventions to change six health behaviours: a review of reviews. BMC Public Health, 2010, 10(1), 538.

[72] GLOBOCAN 2012. IARC, Lyon, 2014.

(Döbrőssy Lajos dr., Budapest, Albert Flórián út 2-6., 1097 e-mail: dobrossy.lajos@oth.antsz.hu) 